\title{
Are Blackouts Landscapes?
}

\section{David E. Nye}

University of Southern Denmark - Odense

\begin{abstract}
This essay reworks J.B. Jackson's definition of landscape in order to make sense of the invention of the electrical urban landscape (1880-) and particularly electrical blackouts, which evolved from expressions of military control (1935-45) to utility breakdowns (1965-) to apocalypse (1977-). As expressed in many aspects of popular culture, temporary failures of the power supply evolved from mere irritations to revelations of an anti-landscape that, unless quickly repaired, was incapable of supporting human life.
\end{abstract}

Keywords: landscape - New York City - blackouts- liminality - electricity - J. B. Jackson - skyline e- utopia - postmodernism - military - World War II - lighting - technology - naturalization.

The term landscape now refers to so many things that it can be in danger of losing its meaning. It no longer refers only to agricultural areas or to places intentionally "landscaped." Writers use it metaphorically and write of the "mental landscape," or create related terms, such as "cityscape." Is another term needed for spaces where the human transformation of nature goes to extremes? Can a physical space be changed to such an extent that it should be called an anti-landscape? I will explore these questions with specific reference to blackouts, or spaces that were created using electrical systems of light, heat, and power but then temporarily lost their sources of energy. Before exploring this subject further, we need a general definition of landscape and a brief history of the development of the electrified landscape.

\section{Defining Landscape}

J. B. Jackson, one of the founders of landscape studies, devised a definition that eschewed artistic categories and recognized the ways human beings are involved in creating the landscape. For him, landscape is "A composition of 
man-made or man-modified spaces to serve as infrastructure or background for our collective existence." As a shared creation, landscape is not something outside human beings that they merely look at, it is humanly modified space. Landscape is not natural but cultural, not merely something secn, but the infrastructure of our existence.

This definition also suggests what an anti-landscape might be: man-modified spaces that once served as infrastructure for collective existence, but which have ceased to be able to do so. Human beings can inhabit landscapes for generations, even millennia, but they cannot inhabit anti-landscapes. The examples of nuclear contamination of Hanford Washington or the chemical poisoning of Love Canal come to mind. One might consider such anti-landscapes to be at the opposite extreme from "original Nature." As long as energy supplies last, the electrical blackout is not as dire a situation as that faced at Love Canal, which is officially uninhabitable, but a blackout does temporarily transform an urban environment into a space that cannot serve as infrastructure of human existence. Instead, the infrastructure becomes a prison that people need to escape in order to survive. One thinks of those caught in elevators and subway systems during a blackout as examples. In a blackout, the city, and also to a considerable degree suburbia, is instantaneously an unsustainable environment.

Each blackout seems temporary when it occurs, but the dysfunctionality of a society without electricity is now a permanent, if usually latent, condition. One might anticipate that a society confronting this situation might take steps to minimize its dependence on electricity or to decentralize its provision. In fact, every western nation has pursued the opposite course, nowhere more vigorously than in the United States. Per capita use of electricity only suggests the rising degree of dependence. Just as crucially, most homes have no alternative systems available except for a few flashlights and candles. Subtract electricity from the infrastructure of American cities and suburbs, and they become an anti-landscape, a place that cannot long sustain human life. Without electricity almost all systems break down. Security alarms do not work, elevators halt, traffic lights cease to function, heating, ventilation, and air conditioning fail, television and radio go off the air, food rots in refrigerators and freezers, all appliances become useless, sewage piles up, and those who seek to flee find that gasoline pumps do not work. 


\section{Developing an Electrified Landscape}

The phenomenon of the electrical blackout was an unintended cultural formation that few thought much about between 1880 and 1930, during the emergence of the brilliant displays of illuminated skyscrapers, the electrified cityscapes, and the Great White Way. Its possibility was hard to imagine in advance. It takes an effort to recapture the sensibility of people living at the beginning of electric lighting, who found a "blackout" to be natural, since it that had lasted for thousands of years. The last 125 years of intensive lighting, from this perspective, is an historical anomaly. Indeed, it still remains an anomaly from the perspective of some living outside the West. A. Roger Ekirch has written a fascinating book, At Day's Close: A History of Nighttime, which recovers the rhythm of daily life in the early modern era when darkness was still normal. ${ }^{2}$ He shows that during the night society did not entirely close down, nor did all activities cease. Rather, there was a division between activities possible only during the day and those consigned to the night, with a firm sense of two different realms of experience. In an electrified society, however, as the abolition of darkness increasingly seemed normal, people expected temporal homogeneity: a life where all activities were possible around the clock.

For most of human history darkness and light alternated in a natural rhythm that varied with the seasons and provided a structure and limits to human existence. Breaking this cycle suggested a breaking of the bonds of nature. Lavish lighting displays at world's fairs in Chicago (1893), Buffalo (1901), St. Louis (1904) and San Francisco (1915) demonstrated the dazzling possibilities. ${ }^{3}$ In these years American popular magazines carried articles about a future world that would be illuminated all night, a world where highly evolved people needed little sleep. Thomas Edison gave credence to such ideas with his public statements, encouraging expectations that electrification would hasten human evolution. ${ }^{4}$

Yet such predictions contrasted sharply with Victorian realities. When Edison began to install electrical generation and transmission systems in 1880 , they at first provided nothing more than local alternatives to the familiar sources of light, power, and heat, usually wood coal stoves, gaslights, kero-

\footnotetext{
2. A. Roger Ekirch, At Day's Close: A History of Nighttime (New York: W. W. Norton, 2005).

3. David E. Nye, "Electrifying Expositions, 1880-1939," Narratives and Spaces: Technology and the Construction of American Culture. (Columbia University Press, 1998), p. 113-128.

4. Thomas Edison, intervicw, "The Woman of the Future" Good Housekeeping Magazine, Oct., 1913, p. 436.
} 
sene lamps, and candles. A generation later, architects often told their clients to install both gas and electrical connections, and only one house in twenty had wiring installed. ${ }^{5}$ As late as 1905 electricity was primarily a public display in the commercial center, but it was not yet embedded deeply in everyday life. The early electrical systems failed often, but there were no blackouts. Every home and business had alternative lighting and energy systems, and the utilities were not yet linked in large-scale networks. Many buildings, such as department stores and large hotels, had their own stand-alone generating plants. There was no regional grid, but a patchwork of local services, which might fail individually, but not collectively. For a quarter century until c. 1905 people gradually grew accustomed to electricity, but they were by no means dependent upon it. The crucial change came in the next quarter century. By 1930 urban Americans had begun to acquire many appliances at home, and they had woven it more deeply into the habits and structures of everyday living.

Even so, if the local power system went out in 1930, the structures of a preelectric everyday life were still available. The vast majority of the American population had grown up in homes without electricity, and a power outage was not terribly upsetting or disorienting. Most homes still had iceboxes, preserving food without any need of electricity. Many women had adopted electric irons, but they still knew how to heat up said irons on a stove, which was almost never electric at that time. Offices likewise could get along without the electric grid. Typewriters and adding machines were mechanical. Copies of documents were produced using carbon paper and saved in file cabinets, along with correspondence. A modern office, even as late as 1940, required electricity for light, elevators, and ventilation; consequently a power failure was a nuisance, rather than a major problem. A power failure that affected more than half of New York and areas north of the city on a winter day in the middle 1930s was news. But it was not called a blackout, and it was not described as a crisis. Mcanwhile, in the countryside as late as $1935,90 \%$ of all farmers lived entirely without electricity, ${ }^{6}$ as farmers always had.

After another generation, however, the electrical system had been woven so tightly into the cultural fabric as to become inseparable from it. Furthermore, the skills needed to survive without electricity were fast disappearing.

5. See David E. Nye, Electrifying America: Social Meanings of a New Technology ( Cambridge: MIT Press, 1990), p. 239-245.

6. Ibid., p. 287-301. 
Americans born after 1930 had little or no experience of life without it. They could not possibly experience a "blackout" as the return to a previous, natural condition. Rather, the blackout was a radical break, a descent into disorientation, an involuntary encounter with and entrapment within the vast machinery of industrial civilization, which most of the time cocoons each individual in comforts and services that are accepted unconsciously, with no reflection on how they are delivered?

At the end of the twentieth century, the artificial environment that depends on electricity for light, heat, power, security, entertainment, and some forms of transportation had been naturalized. When the power fails, "natural darkness' returns, but it is no longer familiar. A power outage in 1900 instantaneously transformed the new electric landscape back into an older, but still familiar scene. The many small power failures of that era did not matter much, because the electrical systems were not interlinked. A century later, the loss of electrical power has a far more powerful effect, because both the artifacts and the experience of the pre-electric world have largely disappeared. A contemporary blackout suddenly reveals a paralyzed space that is dark, difficult, and dysfunctional.

Henry Beston once observed that modern people no longer feel comfortable with darkness. They,

. . now have a dislike of night itself. With lights and ever more lights, we drive the holiness and beauty of the night back to the forests and the sea, the little villages, the crossroads even, will have none of it. Are modern folk, perhaps, afraid of night? Do they fear that vast serenity, the mystery of infinite space, the austerity of stars? Having made themselves at home in a civilization obsessed with power, which explains its whole world in terms of energy, do they fear at night for their dull acquiescence . . . . today's civilization is full of people who have not the slightest notion of the character or the poetry of night, who have never even seen night. ${ }^{8}$

\section{Electrical Landscapes and Blackouts}

Landscapes are cultural constructions that emerge from political, economic, and aesthetic decisions, as is particularly obvious in the case of the electrical landscapes that emerged after c. 1880, such as New York's “Great White

7. For more on how technology can function like a cocoon, see David E. Nye, Technology Matters (Cambridge: MIT Press, 2006), p. 185-207.

8. Henry Beston, cited in Nye, (1990) p. 389. 
Way" or, in recent times, the Las Vegas casino strip. ${ }^{9}$ I have written elsewhere on the intensification of electrified landscapes, the public appreciation for electrical spectacle at world's fairs, amusement parks, and the Great White Way. As the advertising, floodlighting, and street lighting competed for attention, salesmen were able to ratchet up sales to each customer. The unintended result of this free market competition was a brilliant landscape of light that transformed urban spacc into a new form of the sublime. Such spectacles were gradually accepted as a "natural" part of everyday life..$^{10}$ The electrical sublime did not carry within it the possibility of breakdown or radical dysfunction, as it can today. Rather, the electrical sublime had shown that the night could be treated as a canvas which society might paint with lights, bringing out monuments and impressive buildings while erasing the unsightly.

In the classical formulation of Immanuel Kant, the sublime is defined as an object that not only makes a powerful impression the first time, but one that is so impressive as to be absolutely great and therefore equally impressive on successive encounters. ${ }^{11}$ A site such as Niagara Falls or the Grand Canyon does not lose its power with repeated visits. The electrified city also seems to have this effect on observers, luring them repeatedly to ascend to the top of skyscrapers or walk into Times Square to experience the dazzling tapestries of flashing lights. ${ }^{12}$ For the most part, this illuminated cityscape was not planned, although the City Beautiful Movement had attempted to regulate the colors and intensity of lighting, with little success outside a few enclaves, notably Fifth Avenue on Manhattan. ${ }^{13}$ But the kinds of signs banned by such upperclass associations predominated in the commercial heart of most cities. Times Square and the lighted skyscrapers of New York became paradigmatic, and are reprised in films such as Manhattan and Sleepless in Seattle. The urban night cityscape is endlessly reproduced on postcards, whether in Pittsburgh or San Francisco, Boston or Las Vegas, Chicago or Washington. Los Angeles

9. David E. Nye, ed. Technologies of Landscape: From Reaping to Recycling (University of Massachusetts Press, 1999).

10. Nye, Electrifying America (1990), p. 57-69.

11. John Watson, The Philosophy of Kant Explained (James Maclehose and Sons, 1908; New York, Garland, 1976), pp. 490-498. Immanuel Kant, Critique of Judgment [1790] Oxford: Oxford University Press, p. 504.

12. See David E. Nye, American Technological Sublime (Cambridge: MIT Press, 1994), chapters six and seven.

13. See Charles Mulford Robinson, The Improvement of Cities and Towns New York: (G. P. Putnam's Sons, 1902), p. 80, 86-87. 
is often represented as a glittering sea of lights seen from the foothills above. The night skyline has become a signature image of the metropolis, a central landscape of modernity. Yet no sooner had this spectacle been embraced as an essential part of the modern city than a counter-movement began to seek ways to hide this spectacle.

Before c. 1930 the word "blackout" can scarcely be found, with the exception of the theater, where blackouts became a standard part of stagecraft. By 1910 , dowsing the lights became a common way to signal the end of an act. ${ }^{14}$ Still, the term was rare, and was almost never used in either the London Times or the New York Times before $1930 . .^{15}$ Two decades after its emergence in the theatre, however, "blackout" became a military term, as nations recognized the new danger that bombers could rain down explosives. Flight itself was a form of the technological sublime and a thrilling spectacle in its first decades, but from the military point of view it demanded the imposition of darkness as a security measure. The simplest way to achieve this would have been to shut down the power stations themselves. Yet, if this would hide a city from a bombing raid, it would also paralyze it. Blocking out the lights was far more desirable. Thus, there was a double movement in the mastery of electricity. First came the desire for spectacle, extravagantly realized on Broadway and in Times Square and imitated all over the United States, which celebrated modernity, demonstrated mastery over nature, and encouraged utopian visions of the future. But this period of exhilaration was closely followed by the subordination of the electric landscape to the military's quest for strategic invisibility. The inversion of the electrical sublime was not the stars above an otherwise dark landscape. Rather it was the simulation of total darkness on earth, while searchlights probed the heavens.

The first mention of a military "blackout" in the New York Times did not appear until as late as 1935. A short article explained: "Gibraltar will be plunged into darkness for an hour tomorrow night in an experimental blackout between 9 and 10 o'clock in connection with combined military and naval exercises." "'6 Dousing the lights on stage had passed over to an imaginary theater of war. Gibraltar, guarding the entrance to the Mediterranean,

14. The theatrical origins of blackout emerge in a survey of both the London Times and the New York Times from 1910 until 1930, when the term was rarely used at all, and exclusively in the context of show business.

15. Gosta Bergman, Lighting in the Theater. (Totowa New Jersey: Rowman and Littlefield, 1977), p. $278-286$.

16. "Gibraltar to be Darkened Tonight," New York Times, Oct. 3, 1935, p. 3. 
was of obvious military importance, so practicing a "blackout" there seemed logical. Yet, before the year was out whole urban populations were forced to take part in blackouts on a much larger scale. The island of Malta darkened its harbors and towns. On the shortest day of 1935, the entire city of Istanbul acted out an air attack, complete with planes dropping flaming fuses as substitutes for bombs and fire departments rushing to put them out. ${ }^{17}$ Blackouts swiftly moved from an element of military planning to a coordinated civilian exercise in other nations, including not only Western Europe but also Japan. In Tokyo a five-day blackout in 1937 included exacting tests of light control. To make sure the artificial blackout was complete, in some districts the authorities turned off all power from the utilities, to compare the darkness before and after. Aside from practice in logistics and in reorganizing urban life to function in the dark, these pre-war blackouts taught citizens to regard themselves as targets, asked them to rethink their daily routines, reconfigured the appearance of the city, and demanded that every man, woman, and child obey military orders.

Such measures had been unnecessary in World War I, when airplanes had a limited range and could not carry many bombs. After 1919, however, all the industrial countries developed more powerful flying machines for use in future conflicts. The US Army Air Corps read Guilio Douhet's The Command of the Air, which argued that future wars would be won by bombing the enemy's factories, power plants, laboratories, and supply lines. Douhet expected that precision bombing would terrorize and demoralize civilians, destroying the enemy's will to fight. To this end, American military planners put the B-17 into production in $1937 .{ }^{18}$ By then Douhet's theories had already become military practice, in the Japanese bombings of China, in the Spanish Civil War, and in the Italian invasion of Ethiopia.

The level of response to this new threat varied considerably. The British attempted a blackout of London, but the public did not cooperate sufficiently, and the city was by no means hidden. ${ }^{19}$ The French held similar exercises, and perhaps to win over the populace, they focused much attention on developing tasteful alternatives to black air raid curtains. Their studies found that "blackout effects can be achieved without eliminating all light and color." A decorator could use layers of red and green glass "as red absorbs everything

17. "Istanbul Douses Lights in Its First Air Raid Drill," New York Times, Dec. 21, 1935.

18. David Kennedy, Freedom from Fear, (New York: Oxford University Press, 1999), p. 603.

19. Roy Porter, London: A Social History, (Cambridge: Harvard University Press, 1994), 338-340. 
else and the green in turn absorbs the red rays. A combination of blue and orange is equally effective. These facts lead to possibilities for curtain linings, colored shades, etc., for which complementary colors could be used."20 The matter was left to private preference, but among the general population "these scientific facts do not appear to have been widely recognized."

The Germans, less concerned with aesthetic fine points, used black exclusively and were relentlessly effective. In 1937 their war preparations included a blackout of Berlin that tested various forms of air raid curtains, shades on traffic lights, and so forth, as well as trying out powerful searchlights that combed the sky looking for attacking planes. The Third Reich demanded that Berlin's 4 million inhabitants observe the blackout for a week. Although restaurants and business could remain open after dark, their windows had to be shrouded. Traffic lights were turned off, flashlights were verboten and passersby could be arrested merely for striking a match. Precautions became even stricter when an air raid punctuated the "black week." Then all traffic, including trams, came to a complete standstill, and the public had to take shelter underground. The theatre of imaginary battle extended well beyond the city, as "methodical preparations have been made for the general blackout in every city, town, and village in the countryside." 21

The purpose in each nation was not merely defensive. Squadrons of planes flew overhead during each drill, dropping flares, taking photographs, trying to "read" the blackout, and then testing accuracy by dropping harmless dummy bombs. In the United States, such exercises began in May 1938 on Long Island, where the town of Farmingdale and its surroundings practiced a blackout for a modest thirty minutes. Not only was time short, but the area darkened was a small circle, two and half miles in radius. Because the military assumed that an actual raid would not bomb civilian targets, attention focused on protecting an aircraft factory. The New York Times noted: "This spectacular 'blackout' and 'bombing' will climax the war game that has roared all along the Eastern seaboard. . ." 22 Impressive as the exercise may have seemed to the thousands who came out to watch it, compared to the blackouts in Tokyo and Berlin, it was a small event.

In October of the same year the American military held a more extensive

20. "Color and the black-out." Textile Colorist 62, No. 734 (Feb. 1940) p. 106, reported in the Joumal of Home Economics Feb., 1940, p. 414-415.

21. "Reich Gets Ready for 'Black Week," New York Times, Sept. 19, 1937.

22. "Town to 'Black Out' in 'Air Raid' Tonight," New York Times, May 16, 1938, p. 1. 
drill in the Fort Bragg area, which involved 66 towns in North and South Carolina. They discovered a paradox. On "the ground the blackout, particularly in the Fort Bragg area and in the vicinity of Fayetteville, a town of about 15,000 , seemed highly successful." But from the skies the landscape remained quite legible: "from the air, the lights of towns, roads, and automobiles were clearly visible and the raiding bombers had no difficulty finding their objective." The Pentagon discovered that blackouts had to be carefully organized and absolute in order to work. It also found that its new $800,000,000$ candle searchlights could not penetrate clouds at 6,000 feet, and did not pinpoint the attacking aircraft at 10,000 feet. At best the planes "were only 'flicked' by the lights." ${ }^{23}$ From the point of view of those on the ground, the military blackout created an obscure but still viable landscape. Electrical service had not been cut off and it could still help to sustain life. But from the air, the faint visibility of towns and roads marked them for destruction. Traces of electric light, particularly from automobile headlights, made a community vulnerable.

Pacifists and anti-war groups worried that practicing blackouts prepared the population for war and trained civilians to accept military command. There seems little evidence that Americans actively protested against the blackouts. But in 1938, a group of Danish pacifists in Roskilde decided to sabotage three days of blackouts in Copenhagen. They purchased all the fireworks in their city and planned to set them off during the blackout, "to show the whole world that not everybody wants to cooperate in preparations for the next world war." ${ }^{24}$ Once war broke out, blackouts became a way of life for civilians on both sides, and people longed for the night when they could put the lights back on again. Vera Lynn caught this mood in a popular song, "When the Lights Come on, All over the world." 25 Thus the wartime experience completed the naturalization of the new electric landscape. An entirely artificial environment had become the emblem of peace and normality. Darkness, once a familiar part of human existence for millennia, had become temporary, artificial, and intolerable.

23. "Air Raid Black-Out Defends Carolinas," New York Times, Oct. 14, 1938. p. 11.

24. Knud Nordgaard, quoted in "Pacifists Buy Fireworks to Spoil Army 'Blackout." New York Times, Oct. 29, 1938, p. 17.

25. Vera Lynn, lyrics at http://www.stlyrics.com/songs/v/veralynn22394/whenthelightsgoonagain574969. html 


\section{The Postmodern Blackout}

In the second half of the twentieth century Americans for the first time began to speak of unexpected power outages as blackouts. To them, ubiquitous power and light had become natural (and yet also "civilized") while the absence of electricity was increasingly the realm of the unfamiliar, the strange, or the primitive. The naturalization of an electrified world led Americans to harbor further expectations. For if electricity were ubiquitous, then instantaneous, universal communication seemed inevitable, in a line that ran from the telegraph and telephone through radio, television, the computer, email, and mobile telephone. No sooner was instantaneous global communications naturalized than it also became "normal" for objects to interact across enormous ranges of space, linked in an system that monitored movements, tracked transactions, and left electronic "footprints." These communication and cyber-kinetic overlays deepened the naturalization of the original electrical network, hiding further its artificiality. Each overlay also raised the levels of potential disruption that a blackout could cause.

Although a blackout became an ever-greater threat to the proper functioning of society, almost no one out side the utilities thought much about it until 1965, when the largest blackout in history struck the Northeast, darkening New York City, southern New England and the area west, all the way to Toronto. At that moment, the blackout leaped far beyond its earlier meanings. Neither the blackout as minor disruption c. 1905 nor the blackout as wartime necessity made phenomenological sense by the last decades of the twentieth century. After 1965, the blackout was arguably the most powerful form of negation possible, not merely extinguishing the lights, but potentially disrupting all the functions of society, freezing all information systems, all movement, all communication. And to make matters more serious still, the historical subject born after 1925, which is to say most of the population, had no practical experience in coping with such an unelectrified world.

If the blackout emerged in the 1930s as the intentional military negation of peaceful modernity, by the late twentieth century its primary meaning had become that of unintended and unexpected failure. It was no longer a temporary, planned response to an external threat, but rather an unplanned event of indeterminate length, an irruption of systemic weakness, a form of irrationality that came from within. The military blackout demanded that the rationality and order of an electrified society continue under the cover of darkness. It was a mask that disguised a fully functioning system. Its elevators 
still worked, its restaurants were still open, its traffic still moved efficiently. The military blackout was a comprehensive system imposed upon the underlying electrical system, demonstrating two levels of mastery and efficiency. In contrast, after 1965 the blackout was a form of negation. It did not hide an underlying order and purpose, but revealed an underlying disorder. It stranded passengers in subways and elevators, and revealed technical failures and management's miscalculations.

The organized, military blackout gave many citizens a role to play, and was staged as a dramatic event. It was a game whose goal was to render the city invisible, to erase the electrified landscape. As happened again in 2003, the unplanned utility blackout struck without warning, disorienting citizens, who often had no idea what to do in the emergency. Ironically, the blacked out city of 2003 was not entirely dark; indeed, it was far brighter than it had ever been before 1880 . The lights of automobiles clearly marked the major highways, and the emergency lighting of hospitals, police stations, and other public buildings provided some orientation as well. Yet the blackout paralyzed subways, trapped elevators between floors, shut off ventilation and airconditioning in hermetically sealed buildings, crashed computers containing millions of pages of data, and closed down almost every business from New York to Toronto. A military strike that achieved half as much would be judged a brilliant success.

The vulnerability of the modern world suddenly emerges when the lights flicker out, suggesting apocalyptic visions and, quite literally, the dark side of industrialization. Take for example Kurt Russell's 1981 film, Escape from New York, in which New York City is a vast, walled ruin, inhabited entirely by criminals. The de-electrified city becomes a terrifying, lawless place, a landscape of decay and fear. The vision of New York in darkness and ruin also emerged in Billy Joel's popular song, "Miami 2017 (Seen The Lights Go Out on Broadway)" whose lyrics include the following lines:

I've seen the lights go out on Broadway-

I saw the ruins at my feet,

You know we almost didn't notice it-

We'd see it all the time on Forty-Second Street.

They burned the churches up in Harlem-

Like in that Spanish Civil War-

The flames were everywhere,

But no one really cared-

It always burned up there before.... 
I've seen the lights go out on BroadwayI watched the mighty skyline fall. ${ }^{26}$

With such blackout imagery circulating in popular culture, the possible meanings of a power failure included cultural collapse, even apocalypse. This is no longer the modernist darkness of the Great White Way and the military blackout, both of which signified increasing control. Rather, the postmodern blackout is a shadowy harbinger of the end of a high-energy civilization, an anti-landscape that cannot sustain life, and possibly a portent. 